\title{
Deregulation of Financial Services and Liberalization of International Trade in Services
}

\author{
by Francis Lohéac*
}

As the negotiations are beginning again in GATT - a subject on which I spoke here last year to outline the views of European insurers - deregulation and liberalization movements are beginning to flourish throughout the world at national and regional levels.

In this context, the completion of the Internal Market between the 12 member States of the European Economic Community merits attention and interest: that goods, services, capital (and persons) can freely move between 12 countries is an experience in integration unique of its kind and a market of some 350 million consumers will obviously not leave business circles indifferent.

Firstly, I should like to sketch in the framework of the European financial services market by highlighting its features and its limitations and then compare it with similar experience in other parts of the world against the background of the current negotiations to liberalize international trade in financial services.

\section{The European financial services market}

The liberalization of banking, insurance and investment services in the EEC rests on a joint global strategy linked to the fundamental principle of mutual recognition.

\subsection{Mutual recognition and the single licence system}

The 1985 "White Paper" on completing the Internal Market and the Single Act which implemented its guidelines, played a decisive role in the process of integrating Europe's financial markets by defining a new and original strategy based on three principles: minimum harmonization, mutual recognition, home country control.

a) Minimum harmonization: The principle of full and prior harmonization of member States' legislation, complicated by these States' different traditions and legislation, has been abandoned. Only essential differences - the source of the worst distortion of competition should now be dealt with by specific coordination: this new approach has made it possible to inject new impetus into liberalization.

\footnotetext{
* Secretary General of the Comité Européen des Assurances, Paris. Speech given at the 2nd Geneva Forum on the liberalization of trade in services, organized by ASEC (Applied Services Economics Centre) with the contribution of the Geneva Association, Wednesday, 22 May 1991.
} 
b) Mutual recognition: Once minimum harmonization has been achieved, mutual recognition of authorization and supervision in the head office country can be set up because any community undertaking would then be deemed to satisfy minimum joint standards defined at European level. Such a decision on equivalence in fact pits not only economic operators but national regulations themselves against each other: so as not to put their own undertakings at a disadvantage vis-à-vis their competitors established in countries with more flexible or more liberal regulations, strictly regulated countries are being encouraged to follow the latter's lead.

c) Home country control: The principle of minimum harmonization, combined with that of mutual recognition, leads on to a system known as the "single licence": the undertaking, by way of establishment or freedom to provide services, is subject - whatever the Community country in which it exercises its activities - to one and the same supervisory system, that of its home country ("home country control"); the resulting simplification from a supervisory - and managerial - point of view is considerable.

Authorization granted to an establishment by its home country will be its "European passport" for the other 11 Community countries: such an establishment may, under this umbrella, exercise its activities freely without further authorization in countries other than its own.

The new Community strategy based on these three principles is the guiding force behind the implementation of the Internal Market in financial services: banking, insurance and investment services.

\section{I.2. The single licence in the European Directives on financial services}

The same Community policy - to allow different services to exercise their activity throughout Community territory under one single authorization issued by the supervisory authorities of the country of origin and under their control (single licence) - is to be found in all financial sectors.

a) Banks and credit institutions are the first financial services to move onto a single licence system and integrated head office supervision (second banking directive); this is one of the only sectors where all the instruments necessary for accomplishing this have actually been adopted to date.

b) Insurance undertakings: the proposals for the third Life and Non-life insurance directives, which are currently under consideration, are intended to set up the same single licence system in insurance. These proposals - very largely drawn from the second banking directive - essentially harmonize the nature and the amount of assets representing technical reserves (in the form of maximum percentages for investment in a given category) and widen the rules for localizing such assets. A related proposal for a directive on the annual and consolidated accounts of insurance undertakings is aimed at transparency in company accounts and comprises a degree of harmonization of the method of calculating reserves.

Based on such harmonization, the formalities for prior approval of contractual and rating conditions would fall away, leaving instead non-systematic communication within the framework of a posteriori supervision. The regulations relating to insurance do not, however, harmonize either premium taxes or insurance contract law. Distortion which may result because of different national legislation is supposed to be resolved by a strictly 
territorial system of taxation (the undertaking is subject to taxation in the country in which the risk is localized) and uniform international private law (the law applicable in principle is that of the country in which the risk is situated).

c) Investment services: Two proposals for directives, submitted respectively on 16 December 1989 and 25 April 1990, are intended to ensure that non-banking investment undertakings benefit from the same facilities as those granted to credit institutions under the single licence system. Negotiations are currently held up in this sector because of serious differences between member States on the treatment of ex-market operations and direct access of banks to stock markets.

d) Pension Funds: Similar studies are under way so that Pension Funds will be able to benefit from the Single Market.

The principle of mutual recognition, on which the single licence system is based, nonetheless encounters certain limits both in scope and in method of application.

\subsection{Limits of the principle of mutual recognition}

a) The European passport issued by an undertaking's head office covers the activities exercised by that undertaking through a branch established in an EEC country or by way of freedom to provide services from one of its establishments; it does not cover any activities exercised by its subsidiaries. The host member State in fact retains the power to subject to authorization the setting up on its territory of a subsidiary of an undertaking already authorized and supervised in the member State in which it has its head office.

b) Open it may be, but financial Europe is not unreservedly available to foreign undertakings. Agencies and branches of foreign undertakings do not benefit from the European passport in freedom of services but all these undertakings need do is set up a subsidiary in the EEC to be able to benefit, using that subsidiary, from the advantages of the single licence like any other Community undertaking. The majority of large American or Japanese financial services undertakings already have subsidiaries in Europe considered and treated as Community undertakings. But in future, establishing subsidiaries of non-Community undertakings or acquiring holdings in a company already established on EEC territory will be subject to certain conditions of reciprocity provided for in the Community directives. These conditions are so flexible that the idea of "Fortress Europe" is nothing more than a myth. The EEC Commission will only check if European establishments benefit in the third country States concerned from conditions of access and exercise equivalent to those available to the undertakings of these States within the Community (national treatment and effective market access). In the event of discrimination, the Commission may be given a mandate to negotiate, which would not suspend their issuing of authorization. It would only be in cases of serious distortion that the host country supervisors could limit or suspend their decision on requests for authorization or proposed shareholdings.

c) The principle of mutual recognition as a rule only applies to a list of activities generally annexed to the directives (either adopted or the process of being so) in the financial services field, banking, insurance, investment services...

The approach by the Community authorities in directives on the financial services is essentially institutional and sectorial. The specific features of each of these financial services sectors mean that they will be regulated by a body of formally and materially distinct regulations even though overall these texts are based on the same principles (single licence). A 
relative degree of convergence has been noted for a number of years between banking and insurance but this phenomenon is limited to structural operations or to the pooling of distribution networks and only marginally relates to products. If it were to develop, every effort would have to be made to avoid identical services being subject to different constraints depending on which directives covered the operator; this leaves the way open for further consideration which should avoid generalization and take into account the specific features peculiar to each services sector.

d) Although the single licence system by its structure does localize supervisory powers in the hands of the home country authorities, the authorities in the country of activity are not completely helpless even though they are confined to relatively narrow limits.

Othcr than the residual powers they have under the coopcration provided for between supervisory authorities - principally in the event of an undertaking in financial difficulties the authorities in the country of activity may intervene when "general interest" dictates or in an emcrgency. On the other hand, some subjects may continue to be the responsibility of the authorities in the country of activity. In the particularly sensitive sector of insurance, it should be still possible for the authorities in the country of services to retain certain responsibilities especially in fields in which the interests of policyholders, victims or beneficiaries are a determining factor (compulsory insurance, health insurance as an alternative to social security, industrial accidents, long-term life insurance...) if their long-term security - the very object of insurance - is not to be jeopardized.

\section{International financial services markets}

The pace of movements to liberalize and deregulate financial services has quickened throughout the world over the last few years nationally and regionally. In this respect, the European experience of integrating financial services is not only original but unique. The principle of mutual recognition, on which the single market is based, presupposes agreement on a number of basic rules guaranteeing the financial solidarity of an undertaking (minimum capital, quality of shareholders and management, solvency ratios...). These minimum harmonization requirements - which are more than mere financial aspects - are only possible because common interest, mutual confidence and a degree of economic convergence exist between EEC member States. Such conditions are only rarely found in the regional groupings which are being set up or which have been set up throughout the world.

In this sense, a widening of the Community itself might be the surest means of making the intcgrated financial services market available to other European countries. The American financial services market, which remains fragmented between the fifty federal States, doubtless meets the conditions necessary for the introduction of an American "passport" system similar to that proposed for Europe. As for the rest, international agreements modelled in varying degrees on European expericncc - arc often, de facto or de jure in the absence of minimum harmonization, no more than very limited free trade agreements.

\subsection{Extending the internal market by expanding the community itself}

New membership - either single countries or groups of countries - of the European Community would obviously be the most direct way of extending the benefits - and the constraints - of the Internal Market, membership implying the adoption of the entire "acquis 
communautaire". This goal can be achieved via parallel mechanisms of association which do not, as such, require formal membership. The current negotiations on the European Economic Area, which in essence seek to extend to EFTA member countries the benefit of the three fundamental freedoms of the Treaty of Rome, can be seen in this context. In the financial services field, associations such as this are helped by the fact that several EFTA member countries have already largely anticipated integration of the "acquis communautaire". Negotiations are currently stalled on other issues (agricultural and fishing products, participation in the decision-making process...). Could wc not, in fact, once this stage has been completed, be moving rapidly towards a series of individual membership demands (Austria, Sweden, Switzerland...)?

The current negotiations on bilateral association agreements betwcen the EEC and Hungary, Poland and Czechoslovakia also fit into the framework of medium or long-term widening of the Internal Market even though, pending sufficient convergence of economic systems, the integration process would of necessity have to be gradual. It is interesting to note in this respect that the reform of financial serviccs begun in these countries in cooperation with the Community is largely modelled on Community directives on the subject.

For their part, the six EFTA countries plus Hungary, Poland and Czechoslovakia are proposing to set up a free trade area which would gradually be built up over the next few (10) years; the first stage, which could enter into force on 1 January 1992, would cover industrial products.

\subsection{Towards a financial services market in the USA}

The organization of financial services in the United States is characterized by sectorial fragmentation and geographic separation which are real obstacles to the fluidity of the market. By comparison, the European market looks less restrictive: on the eve of the Single Market, it is clearly less difficult - and less costly - for an undertaking to set up a network there.

a) Banks

In addition to complex State regulations, American banks are subject to federal legislation which restricts opportunities to expand banking activities. This rigid regulatory system which weighs heavily on competitivity in the sector encouraged the American Treasury to propose to Congress a radical change in the banking system. The proposed modifications aim particularly at closing the gap between deposit banks and mcrchant banks, lowering the barriers which stop banks from being taken over by industrial or commercial undertakings and the establishment of networks covering the entire country. In this respect, the obligation of foreign banks to set up subsidiaries for the activities of their branchcs in the US in a holding company worries European banks.

The introduction of a single licence system would make it possiblc to remove some difficulties surrounding market access which are currently to be found in banking and in insurance and would, in this respect, be in linc with the logic behind the Uruguay Round negotiations.

b) Insurance

Unlike banks and investment services, insurance in the USA essentially comes under the federated State regulations; life insurance of the traditional type is however clearly distinguished from insurance of the pension type which comes under federal regulations. 
In insurance, the same phenomenon of strict limitation of scope and fragmentary supervision can be seen: an insurance company wishing to exercise in a State other than the one in which it is established must obtain in each of these States one, and sometimes more authorizations depending on the nature of the operations proposed. The same applies to intermediaries. The American authorities are proposing to revise their regulations on insurance (McCarran Fergusson Act) so that the federal government would have a greater role in supervision; some powers would however be retained by the State authorities.

\subsection{Regional trade agreements}

The difficulties linked to organizing an integrated market obviously grow in proportion to the cultural, economic and legal differences between the States concerned. The more States there are, the more the differences in the systems become visible and the more difficult it becomes to combine the minimum conditions essential for integration. This is why multilateral agreements which have been adopted or are under preparation are, generally speaking, less ambitious than the Treaty of Rome or, at all events, have not so far been able to achieve their ambitious targets. A few examples will illustrate this:

a) In South America and Africa

The framework agreement signed in 1991 between Argentina, Brazil, Paraguay and Uruguay to set up a South American Common Market (MERCOSUR) has aims which are basically similar to those of the Treaty of Rome: the Treaty of Asunción is intended to set up, from 1995, a vast economic area within which, just like the EEC, goods, persons, services and capital may freely circulate.

The members of the Andean Pact - Bolivia, Columbia, Ecuador, Peru and Venezuela - also favoured on 18 May the creation of an Andean free trade area which should become effective from 1 January 1992; the Andean Pact is however far from achieving the aims which it set out for itself on 31 December 1980: customs union, joint development programmes, joint foreign investment schemes...

The member States of the Organization of African Unity (OAU) at their 27th summit at the beginning of June should be signing a treaty to set up the "African Economic Community" set out as a "Treaty of Rome" for Africa.

What is the future for such groupings of economies in crisis which scarcely attract foreign currency, and what is their capacity to achieve in such a short time an integrated market, particularly in the field of services? Such associations do have other specific aims as well: they are intended to provide back-up for restoring their members' economies, give impetus to growth and development of their exports and reinforce their negotiating power within international bodies; they also reflect current deregulation and privatization movements in certain States (in particular Argentina, Brazil...) which are signatories of these regional agreements.

b) In Asia and the Pacific

ASEAN - the Association of South East Asian Nations - is the oldest organization in this area (set up in 1967) and includes Brunei, Indonesia, Malaysia, the Philippines, Singapore and Thailand. In a context of very sustained economic growth, some countries want to see the interdependence of the region's economies reinforced. Malaysia in particular is proposing the setting up of an "Eastern Asian Economic Group" (EAEG) which would comprise the six ASEAN member States, Myanmar (Burma), Cambodia, China, South 
Korea, Hong Kong, Japan, Laos, Thailand, Taiwan and Vietnam. Japan, which is in favour of the emergence in the region of a sphere of political and economic corporation, feels however that conditions are not yet ripe for the constitution of a purely Asian zone; the US in fact supports a wider initiative, the Asian and Pacific Economic Conference (APEC), set up two years ago, which joins the six ASEAN members, South Korea, Japan, New Zealand, Australia, Canada and the US.

\section{c) In North America}

At the same time, the concept of a major North American market including the US, Canada and Mexico is also making progress since the American administration officially programmed the opening of negotiations to reach an agreement similar to that signed on 2 January 1988 between Canada and the US making their trade association official. The Mexican economy and the foreign debt problem held up this process for a long time, especially since Mexico was not resigned to the loss of sovereignty which the signing of this agreement would involve.

Although the signature of this "Trade Agreement" would doubtless enable a balance between abundant Mexican labour and Canadian and US technological advances to be found, combining a developing economy and advanced capitalist economies does leave some doubt as to the success of any such move which would at all events only lead to a free trade agreement with less grandiose ambitions right from the start than those of a genuine integrated Commom Market.

Even the bilateral agreement signed in 1988 between the US and Canada (which entered into force in 1989) is no more than a free trade area. The Free Trade Agreement, according to estimates, covers $20 \%$ of products not already subject to customs duties between Canada and the US and for financial services the relationship between the two countries is still based on the principle of "national treatment". The imbalance at this level is manifest since American financial institutions can benefit from the deregulation and desegregation of financial services in Canada ${ }^{1}$ but inversely, Canadian banks draw no benefit from any reciprocity and consequently remain subject to the different constraints which divide the American financial services market.

Despite their limited nature, the many regional agreements to liberalize trade demonstrate the depth of the current liberalization movement and in this respect might be seen as auguring well for the GATT negotiations.

\section{d) $G A T T$}

The multilateral trade negotiations in GATT are the subject of a multi-sectoral global approach centered on the removal of the restrictions to trade in products and services. The essential aim of these negotiations insofar as insurance is concerned is the free exercise of freedom to establish. This aim presupposes the abolition of obstacles such as discriminatory conditions of authorization, exclusion of foreign insurers from certain activities, obligation to set up companies under local law, obligation to reserve for nationals part of the capital

1 The reform of the Canadian financial system essentially consists of abolishing the barriers between commercial banks and investment banks and between different financial services in general. When this programme of deregulation is complete, all services undertakings including insurance companies may offer the complete range of their financial services throughout the country. 
or a given number of seats on the board, employment quotas, tax discrimination, legal or compulsory ceding to national reinsurers, deposits...

In a GATT context as broad as this, setting up a system of freedom to provide services - and a fortiori a single licence - would be pure utopia. The experience of the European Economic Community demonstrates the difficulties of such a revolution even in geographically close and culturally similar countries. It is therefore essential that the GATT negotiations have as their priority the liberalization of freedom to establish, subject to the important reservations of maintaining and developing freedom of transfrontier activity for reinsurance and insurance linked to international trade and transport.

This liberalization should be based, for insurance as for other sectors, on the three fundamental principles of transparency, national treatment and non-discrimination: clear and detailed information on conditions of access and exercise: equivalcnt de facto as well as de jure treatment of national and foreign insurers both from the point of view of conditions of establishment as well as prudential rules in the investment of assets, aimed at effective access to the markct; by virtuc of the "most favoured nation" clausc, immediatc and unconditional extension to all other contracting parties of any negotiated advantage autonomously granted by a signatory.

The world of international trade and especially that of financial services, is currently living in an atmosphere of deregulation and liberalization. In the first instance, this movement concerns the State themselves, which are increasingly undertaking economic reforms along these lines (in Europe, the opening up of Eastern Europe, privatization in Ireland, Portugal, UK, Germany; in North America, deregulation in many sectors in the US ; economic reforms in Brazil, Argentina...). These reforms often also tend towards deregulation of transfrontier trade and the conclusion of bilateral or multilateral agreements with the movement gradually extending to cover ever larger regional groupings.

It is to be hoped that these new, more or less integrated, regional groupings will not form closed blocs but will be open to trade with all their partners; the temptation - sometimes vigorously displayed - to substitute a bilateral approach for multilateral negotiations on services is, in this respect, very worrying. To avoid sterile and eventually dangerous assumptions not based on facts, the EEC, which has gone furthest down the road of regional integration, must give a loud and clear signal that it intends to accompany this with a broad opening to the world. The legitimate concern of prescrving ccrtain traditional sections of the economy should not compromise the pursuit of the liberalization of international trade in goods and services. 